FACTA UNIVERSITATIS

Series: Physical Education and Sport, Vol. 18, No 2, 2020, pp. 457 - 464

https://doi.org/10.22190/FUPES200630043V

Professional article

\title{
SECURITY MANAGEMENT IN SPORT
}

UDC 796.075

\section{Jovan Veselinović, Aleksandra Perović, Stanimir Đukić, Gordana Mrdak, Marija Nikolić}

Faculty of Management in Sport, Alfa BK University, Belgrade, Serbia

\begin{abstract}
The paper deals with the practical application of management and commercialization in sports. It also examines the forms of endangering internal security, prevention of violence and misbehavior at sporting events and the security of the state and society. Management as a dynamic discipline represents leadership in each organization. It implies optimal use of resources, organizing the processes and activities of subordinates, delegating tasks and responsibilities, coordination of all resources through planning, organization, management and control. Management in sport, or in a sport organization is in the function of transferring ideas to the ultimate goal. In this regard, it can be said that application of management in sport is a successful pursuit of the idea to the realization of the goal. Management of each organization, including management in sports, gives special attention to security as the basic condition of survival and prosperity. Different organizations have different security challenges, risks and threats, so the risks that the state as an organization exhibits differ greatly from the challenges that business entitles are exposed to, including sports and sports organizations. Challenges, risks and threats that an organization is exposed to, especially in sport, as well as the responsibilities of an organization towards the environment in terms of safety, have a decisive influence on management in sport, that is, to the manner in which the decisions regarding security and protection of persons, property and business will be made.
\end{abstract}

Key words: Management in Sport, Security, Misconduct at Sports Events

Received June 30, 2020/ Accepted July 14, 2020

Corresponding author: Jovan Veselinović

Faculty of Management in Sport, Alfa BK University, Palmira Toljatija 3, 11070 New Belgrade, Serbia

Phone: + 3812674164 •E-mail: jovan.veselinovic@alfa.edu.rs

(C) 2020 by University of Niš, Serbia | Creative Commons License: CC BY-NC-ND 


\section{INTRODUCTION}

When it comes to management as a discipline, it is applicable in different fields and organizations. There is educational management, public services management, company management, police management, etc. Hence, there are many different types of human practice and techniques of management. The basic task of management in every organization is to increase the vitality of organization and its ability to survive in different circumstances, including the prosperity and growth of an organization. The way that management handles questions of safety in the first instance depends on the general goals of the organization. In that way a difference between safety management and management of cooperative safety in organizations which provide safety to other users and customers can be made. They are both in the function of the preservation and growth of the organization. Most economic and sport subjects, sport organizations, have certain properties, infrastructure, capital and other values which can be at risk of physical destruction and other forms of expropriation (Đukić, 2017: 3 ). Millions of people around the world are excited and fascinated by competition sport. People are willing to pay to see elite athletes and elite sport performances. Sport dominates the media, it can bring millions in just one season and sport goods are always so very popular. Today the word "safety" is quite present in all of the languages and cultures i.e., in different areas such as sport, politics, health, IT technology, ecology, psychology, economy, finance, architecture etc. When it comes to inner safety, what is worth mentioning are sociopathological types of endangerment (criminal, drug abuse, prostitution, alcoholism, gambling), extremities, obstruction of public peace and safety etc. (Đukić, 2018: 142). There will be a special accent on the endangerment of sport activities, performances and other sport festivities.

The paper deals with the practical application of management and commercialization in sports. It also examines the forms of endangering internal security, prevention of violence and misbehavior at sporting events and the security of the state and society.

\section{THEORETICAL CONSIDERATIONS OF THE PROBLEM}

\section{Defining management in sport}

Management in general is a multiple concept which requires different elements of the market. In its first and most common meaning it represents the process of managing different businesses and activities, the correlation of jobs and responsibilities, organizations, leadership and control. The word management is an English word which means to manage companies or different public resources. Its beginnings are related to the terms of industrialization. Although its roots stem from the early past it is important to mention that providing new methods and technologies increases profit, and the term itself becomes more popular (Životić \& Veselinović, 2018). The division of capitalist society into the public and private sphere found its expression in management. But, the term of management has been used more often in managing companies while the police and army used other terms, such as leadership and commanding as the special functions of management. Managers are people that basically rent out their knowledge and leadership (Životić, Ilić, Veselinović, \& Bačevac, 2019). Management means coordinating activities connected to businesses. Being a manager means to act efficiently and effectively perform a job in organizations connected to work, or it is at least what managers are trying to achieve (Đukić, 2017: 10). In the case of the term of "sport", 
in the modern world its main meaning is related to the competition and struggle for the best results, but it can also be seen in a much broader meaning. There are so many different definitions of sport which define the term and its meaning.

The common characteristic of different definitions is that it is public work (a physical activity) and it is a struggle for higher accomplishments. Regarding that we will number some of the definitions of sport: "By sport we mean defining different physical activities as a subject of mastery, strength, ability of a man to incorporate different elements of competition, leadership, record or maximal results as a specific form of competition" (Matveev, 2008: 81). Based on these definitions it is clear that sport is fun, a game, physical practice and psychophysical activity connected to competition (struggle) for measurable results (Nešić, 2008: 10). When seen as a human activity sport has the following characteristics: 1) Competition; 2) Result; 3) Specialization; 4) Utility (sport has through its whole evolution been in the service of educational, health and recreational needs); 5) Complex social phenomena. Sport activity is an organized activity of a larger number of people with a basic function - providing conditions for the needs of groups of people or a whole society. An activity that is based like this has in the goal of setting the standards of certain subjects (Nešić, 2008).

The basic and fundamental part of sport are sport resources, too. Sport people and sport organizations are a part of a system basic to the sport. A sport organization itself is an "organism" which provides a sportsman with its full potentials and new values. Management in sport, and in sport organization, means that all of the processes and resources are in the function of transfer to its final goal. It can be said that management in sport represents successful leadership of ideas to the final goal. By defining it this way, management in sport provides the functioning of the whole system of sport organization, from talent selection to the professional work of organizing sport competitions, providing material and financial resources and communication of all the processes in one sport organization. In the first place it concerns its stability and position in society, sport results, business results, work efficiency, etc. At the same time, it has the function of basic development of sport in general and of the sport organization, too.

When it comes to defining the basic principles of management in sport according to Tomić (2001) they include: 1) Developing sport by conserving its mission and spirit; 2) Fulfilling the goals of multiple publicity; work efficacy, etc.; 3) Developing a stable sport organization; 4) Development of creative capacities; 5) Decentralization and delegation of authorities; 6) Application and development of all the functions of management. Management in sport must apply and develop all the functions of management: planning, organizing, prediction, leadership and control. Every function by itself would not mean anything without the interaction of all its parts (Nešić, 2008: 79).

\section{Practical application of management in sport}

The practical application of management in sport, as the organization of work in sport organizations and management in sport, consists of: 1) aspect of studying and 2) aspect of practical knowledge which is being studied. In the first part of the paper it was mentioned that management is a process, which means cyclic process through five functions which managers realize by preparing and controlling an organization and its process. Regarding that, management in sport as an academic discipline unites knowledge on the management of sports organizations. As an example, there is the United Commission for Physical 
Education and Sport Management of North America, for the evaluation of sport managers at the Universities of North America. Its standards are given as follows: a) Studying of sociocultural dimensions of sport; b) Management and leadership in sport; c) Ethics in sport management; d) Marketing in sport; e) Communication in sport; f) Budget and finance in sport; g) Law aspects of sport; h) Economy of sport; i) Management of sport objects and festivities; f) Leading bodies and structures in sport; and h) Practical experience in sport management (Raić \& Maksimović, 2001: 5-6).

The efficient and well-designed organizational structure of a sport organization is a basic necessity the for realization of defined plans. Forming an organizational structure includes the entire spectrum of actions on defining roles and assignments, competitions and regulations, norms of behavior, as well as hiring resources in sport organizations which are in function of certain goals and the defined policies for its realization. Structural defining, or the design of one organization is a major activity of a manager in sport. In economic activities, as in sport organization, managers assign jobs and divide the activities of integration-grouping jobs by sectors. After that division, leadership takes its part in the coordination of activities and management of efficient communication inside the organization (Veselinović, 2012: 78).

In the case of control in sport, it is always applicable on measurements of results of one club i.e., the projected goals of a sport organization. In companies, the control process functions between planned and accomplished and corrective actions. Regarding the obligation of one club, especially in professional sport, there is a need for business books and balances which are delivered once a year. The financial aspect of a club is among one of the most significant terms of functioning. Control as a function of a training process and sport activities are of great significance. Clubs that have precisely regulated financial aspects of business are better positioned than the ones that do not have it. Clubs can also hire professional managers (Jones, Wicks, \& Freeman, 2002).

In this case there is a need for the management strategy of. Financial aspects are defined by sport federations which are doing their part of the work, while the internal part of business in clubs is done by the committee of the club. Publicity in the work is perhaps the best way of controlling the management in certain club. Managing leadership and above all financial control in terms of guaranteed deposits of future candidates for leading functions in elite sport is the only way to restrain bad practice (Šurbatović, 2014: 103).

\section{Commercialization of management in sport}

Commercialization in sport, especially in the professional one imposes the following questions, of which the second one is crucial: "Which moral principles need to restrain sport commercialization?" Whose responsibility is it to maintain those principles?" Part of the commercialization process is a transformation of many sport professional organizations into corporations. Companies are not in the world of sport. It is not in the best interest of professional teams, sport organizations or the best sport players to encourage violent behavior between players or inside the whole society. The term "corruption" means falling apart, distancing from the original principles which were noble in the first place. Corruption means that the original values that have been in sport such as fair play, sport behavior and a constant search for excellence. The fact that elite sport is connected highly with commercialization is especially problematic, as is the connection between mass sport and mass players. Critics have always claimed that the promotion of elite sport and elite competitions has a 
very bad influence on sport. For example, in his quite provocative book "Sport in America" Michener (1976) claimed that promoting talented sport players between 15 to 22 years of age is not good in general, because in that way we are not promoting the ones that are between 23 and 75 years of age. Since Michener's book has been published there has been a significant decline of physical activity in public schools in USA and consequently higher rates of obesity among American youth, hypertension and diabetes, problems that earlier had been connected only to middle age people.

Maybe the biggest concern is the one that commercialization can endanger the sport itself. For example, changes in the rules of the game can make a game more interesting and popular for some people. However, it can have enormous side effects. For example, with baseball players in the American League the game became more interesting to those that needed more action and more home runs, but it decreased a need for subtle strategy decisions, such as replacement of the players or rejection of the ball. Maybe an even better example is judging the NBA league. Commercialization can influence sport competitions in many other ways. For example, during the "television time out" the game is interrupted for the purpose of commercial breaks during TV shows, especially in professional and college basketball, which influences game results in general. There is a significant impact of large amounts of money in professional sport which gives the richest clubs a chance to win. If wealthier clubs can buy best players and have a better team even before the game started, is there a question of ethics? In the same way a need for profit can prolong the whole season and the players in that case do not give the best performances until the very end of the game. They do not play the best they can during the season and the usual season is merely an adaption for a post seasonal game. At the same time, onlookers pay more and more to watch games during the regular season.

Besides, influence of the money can change the relationship between players and those who watch the game. With the commercialization of the sport in general, players also become goods that can be bought, sold and changed between teams. As a result there is less humane treatment and more commercialization which is not good. Players become untouchable and distanced. Professional teams aspire to create profit, the prices of tickets are very high (Robbins \& Coulter, 2005). As sport becomes more and more interesting and less balanced it focuses more on knowledge and respect for tradition. Commercialization of sport, transformation of elite sport into the final product which can be bought and sold, ruins sport itself. Values of sport can be contrary to traditional postulates of the sport. As McNamee (2015) said, commercialization of sport introduces search for the money and fame and eliminates those involved in sport to compete, to win and to express other human qualities.

Experience in sport according to Morgan et al. proscribes a corruption thesis, becomes an instrument for the biggest external awards such as money, fame and fortune. The significance of internal awards is being diminished. Whether the commercialization corrupted sport or has it made to feel more acceptable for millions of viewers is a question for further discussions.

\section{Moral responsibility of sport management}

When it comes to business in general and about the moral aspects the question is which moral restrictions are applied onto professional sport teams and major leagues. According to one perspective sport teams must provide protection for the environment, but no other obligations are needed. There is a constant race for profit in every team and sport is becoming more and more commercialized (Radaković, 2016). 
If the sport industry is only for fun and entertainment then what happens with the moral principles and other positive aspects that sport should bring?

According to Barry (1989) if personal profit is left on one side, would it be morally correct to change the game and its basic values? What if one team is that much superior that it cannot put any limits on its work, and the other team is that much inferior that it cannot compete with a much stronger team. It seems that these arguments are opposite to the moral principles they represent.

Based on these views it can be concluded that owners of the clubs and players make profit, while supporters enjoy the given game.

Preserving fundamental values of sport is what keeps fundamental principles alive and makes sport interesting. For those reasons members of the sport industry should not let those values disappear or diminish.

\section{Security management in sport}

By the law of nonviolence and nonviolent behavior on sport events there are different measures that prevent violence and indecent behavior during sport festivities and about the obligations of the public services in conducting those measures (Official Gazette of the Republic of Serbia, 2003; 2005; 2007; 2009; 2013; 2018; 2018a). The organizer of a sport event, in the terms of this law, is a sport club or other legal or physical person that organizes sport events or executes other sport activities. The sport event, in the meaning of this law, is framed in a time interval of two hours before one sport event and two hours after the sport event (when there is a higher security risk). Participants in this sport event are, in the term of this law, all the persons present in one sport manifestation. Sport objects in terms of this law should have a part for the spectators and can have other spaces such as a wardrobe, sanitary facility and basement. A sport course, in terms of this law, is a place a where sport activity takes place (sport game, competition).

The organizer of a sport event, in cooperation with the Ministry, is obligated to have safety at a higher level of security and to prevent indecent behavior. Violence and indecent behavior during different sport events includes: a) physical assault on the participants of one match during one sport manifestation; b) throwing objects on sport court or the audience seats; c) entering a sport object with indecent signs which disrespect national, political and other feelings which can lead to physical assault; d) destroying sport objects, inventory, installation and other facilities where the sport event is being held; e) causing trouble or destroying property when coming or going from a sport event or endangering other participants at a sport event or a third party; f) illegal entrance on the sport court and other public places or objects for the spectators; g) attempt to bring pyrotechnics into a sport object and other objects which can endanger other participants; e) attempt to enter a sport object with alcohol or other opioids; h) igniting fireworks and other related objects; and i) wearing hats, scarfs and masks with the intention of hiding one's identity.

In relation to the abovementioned, there is a to-do list for clubs in order to prevent indecent behavior:

1) To promote organizing and good behavior of the players and spectators during and after sport manifestations;

2) To inform its spectators on the consequences of bad behavior;

3) To coordinate organizing activities with the police;

4) To take other measures and activities according to the law and based on sport rules; 
5) To forbid access to a sport object for persons who are intoxicated or are manifesting indecent behavior;

6) To separate entrances and exits of sport objects;

7) To mark exact places by numbers for the spectators to sit on;

8) To enable entrance of spectators on a sport court and their moving from one part of the court to another;

9) To disable consumption of alcoholic drinks during sport events;

10)To disable entrance to sport objects to persons carrying pyrotechnics and bottles, mirrors, lasers, signs which promote racial and national beliefs;

11) To disable the promotion of symbols of bigger dimensions which can be a problem for other spectators;

12)To remove spectators who are dangerous for sport events or endanger others.

The organizer should have very close contact with the Police Department in enforcing those measures and also to organize medical help and other similar services such as the Fire Department, Inspections and Communal Services.

\section{Ways to endanger inner safety in sports}

When it comes to safety of the society and state, it is integral and united. Modern states are being attacked on every field (family, faith, government, politics, economy, sport, etc.) and should be defending themselves with all their might (Đukić, 2018). Considering the classification of safety, it could be divided into inner (individual, social and national) and external safety (regional, global, collective and cooperative). Each of them has special values of a safety system and social precautions. Inner safety refers to the economy, politics, the law and social security of the citizens.

Public peace and safety is the result of coordinated interaction between citizens according to the Law of public peace and safety, caused by their public behavior and by organizations in public life and citizens guaranteed by the Constitution (Official Gazette of the Republic of Serbia, 2016; 2018).

Disturbance of public peace and safety during sport events is very common and it has no implications for a sport but to all sports in general (local, international or national). Some sport events are considered of "higher risk" and involve the police force and Police Department.

\section{CONCLUSION}

Management in sport, or in sport organizations is in the function of transferring ideas to the ultimate goal. In this regard, it can be said that the application of management in sport is a successful pursuit of the idea to the realization of a goal. Management of each organization, including management in sports, gives special attention to security as the basic condition of survival and prosperity. Different organizations have different security challenges, risks and threats, so the risks that the state as an organization exhibits differ greatly from the challenges that businesses are exposed to, including sports and sports organizations. Challenges, risks and threats that an organization is exposed to, especially in sport, as well as the responsibilities of an organization towards the environment in terms of safety, have a decisive influence on management in sport, that is, on the manner in which decisions regarding security and protection of persons, property and business are made. 


\section{REFERENCES}

Barry, B. (1989). Theories of justice. Los Angeles: University of California Press.

Đukić, S. (2017). Osnove i sistem bezbednosti u Strategiji nacionalne bezbednosti (Fundamentals and security system in the National Security Strategy). Vojno delo, 69(7), 100-121. In Serbian

Đukić, S. (2018). Menadžment korporativne bezbednosti i kriminalitet kao oblik i izvor ugrožavanja bezbednosti korporacija (Corporate security management and crime as a form and source of threats to corporate security). Vojno delo, 70(5), 99-117. In Serbian

Official Gazzette of the Republic of Serbia, No. 85/2016 \& No. 24/2018. Zakon o javnom redu i miru (Law on public order and peace). In Serbian

Official Gazzette of the Republic of Serbia, No. 67/2003, No. 101/2005 - law, No. 90/2007, No. 72/2009 - law, No 111/2009, No. 104/2013 - law \& No. 87/2018a. Zakon o sprečavanju nasilja i nedoličnog ponašanja na sportskim priredbama (Law on prevention of violence and misconduct at sports events). In Serbian

Jones M.T., Wicks, A.C., \& Freeman, R.E. (2002). Stakeholder theory: The state of the art. In: N.E. Bowie (Ed.). The Blackwell guide to business ethics, (pp. 17-37). Blackwell Publishers.

Matveev L.P. (2008). Teoriya $i$ metodologiya fizicheskoy kultury (Theory and methodology of phycical culture). Moscow: Sport Akadem Press. In Russian

McNamee, M. (2015). Ethics and Sport. In: M. McNamee, \& W.J. Morgan (Eds.). Routledge handbook of the philosophy of sport, (pp. 131-141). Routledge: London, New York.

Michener, J. (1976). Sports in America. New York: Random House.

Nešić, M. (2008). Sport i menadžment, treće dopunjeno i izmenjeno izdanje (Sports and Management, third amended and modified edition), Sremska Kamenica: Faculty of Business in Service, Educons University. In Serbian

Radaković, M. (2016). Komercijalizacija u sportu (Commercialization in sport). Novi Sad: Faculty of Sport and Tourism-Tims. In Serbian

Raić, A., \& Maksimović, N. (2001). Sportski menadžment (Sports management), Novi Sad: Faculty of Physical Culture. In Serbian

Robbins, S., \& Coulter, M. (2005), Menadzment-osmo izdanje (Management-eight edition). San Diego State University. Belgrade: Data status. In Serbian

Tomić, M. (2001). Menadžment u sportu (Management in sport). IP „Astimbo“, Belgrade. In Serbian

Šurbatović, J. (2014). Menadžment u sportu (Management in sports), Belgrade: JP Zavod za udžbenike. In Serbian

Veselinović, J. (2012). Menadžment sportske organizacije (Sports organization management). Belgrade: Sports Association of Serbia. In Serbian

Životić, D., Ilić, R., Veselinović, J., \& Bačevac, S. (2019). Leadership in a contemporary sports organization. Facta Universitatis Series Physical Education and Sport, 17(2), 247-258.

Životić, D., \& Veselinović, J. (2018). Modeli funkcija u sportskom menadžmentu, dopunjeno izdanje (Function models in sports management, amended edition). Belgrade: Faculty of Management in Sport, Alfa BK University. In Serbian

\section{MENADŽMENT BEZBEDNOSTI U SPORTU}

$U$ radu se razmatra praktična primena menadžmenta $i$ komercijalizacija u sportu. Takođe, razmatrani su najvažniji aspekti zakonskog okvira u pogledu sprečavanja nasilja i nedoličnog ponašanja na sportskim priredbama $i$ bezbednost države $i$ društva. Menadžment kao dinamična disciplina, predstavlja vođstvo u nekoj organizaciji. Menadžment podrazumeva optimalno korišćenje resursa, rukovođenje procesima i aktivnostima podređenih, delegiranje poslova i odgovornosti, koordinaciju svih resursa putem planiranja, organizovanja, vođenja i kontrole. Menadžment u sportu, odnosno u sportskoj organizaciji je u funkciji transfera ideje do konačnog cilja. S tim u vezi, može se reći da primena menadžmenta u sportu predstavlja uspešno vođenje ideje ka realizaciji cilja. Menadžment svake organizacije, pa tako i menadžment u sportu, posebnu pažnju poklanja bezbednosti, kao osnovnom uslovu opstanka i prosperiteta. Različite organizacije imaju različite bezbednosne izazove, rizike i pretnje, pa se tako rizici kojima je izložena država kao organizacija u velikoj meri razlikuju od izazova kojima su izloženi privredni subjekti, odnosno sport i sportske organizacije. Izazovi, rizici i pretnje kojima je izložena neka organizacija, posebno sportska, kao i odgovornosti koje organizacija ima prema okruženju u pogledu bezbednosti, presudno utiču na menadžment u sportu, odnosno na način na koji će biti donete odluke vezane za bezbednost i zaštitu lica, imovine i poslovanja.

Ključne reči: menadžment u sportu, bezbednost, nedolično ponašanje na sportskim priredbama 